\title{
Perbedaan Pengaruh Parasetamol dan Parecoxib Terhadap Aktivitas Agregasi Trombosit pada Pasien SIRS atau Sepsis
}

\section{The Differences Effect Paracetamol and Parecoxib to Platelet Aggregation Activity on SIRS or Septic Patients}

\author{
Admaji Wibowo ${ }^{\bowtie *}$, Purwoko*, Suradi** \\ *Bagian Anestesi dan Terapi Intensif, Fakultas Kedokteran, Universitas Sebelas Maret, Surakarta, \\ Indonesia \\ ${ }^{* *}$ Bagian Pulmonologi, Fakultas Kedokteran, Universitas Sebelas Maret, Surakarta, Indonesia \\ ${ }^{\bowtie}$ Korespondensi: admaji83@gmail.com
}

\begin{abstract}
Background: Paracetamol and parecoxib is Non Steroidal Anti Inflamatory Drugs (NSAIDs) which widely used to treated patients with Systemic Inflammatory Response Syndrome (SIRS) or sepsis in the ICU as an antipyretic and anti-inflammatory drugs. Both of these drugs can affect the platelet aggregation that can be checked with the platelet aggregation test.
\end{abstract}

Objective: To understand the difference between between paracetamol and parecoxib to platelet agregation activity on SIRS or Septic patients.

Methods: This research was an experimental experiment with clinical approach before and after the experiment. there were 34 SIRS or septic patients in the ICU between the age of $17-65$ years old as the experiment subjects. Sampling distribution was devided to 17 subjects that were given paracetamol and 17 subjects that were given parecoxib. After we randomized it, we checked the platelet aggregation before and 120 minutes after the treatment with an $10 \mu M$ adenosine diphosphate (ADP) nductor.

Results: Based on the Mann Whitney test on the unpaired group, the result was $p=0.310$, which means there was no significant difference of platelet aggregation between paracetamol and parecoxib group before the treatment and the result after the treatment was $p=0.013(p<0.05)$, which means there was significant differences of platelet aggregation between paracetamol and parecoxib group. And we did the Wilcoxon test on the paired group, and the result was $p=0.020(p<0.05)$, which means that there was significant differences of platelet aggregation before and after administration of paracetamol.

Conclusions: The use of paracetamol was effective in decreasing the platelet aggregation that significantly difference compared with parecoxib $(p=0.013)$.

Keywords: NSAIDs; paracetamol; parecoxib; platelet aggregation; septic 


\begin{abstract}
ABSTRAK
Latar Belakang: Parasetamol dan parecoxib adalah Obat Anti Inflamasi Non Steroid (OAINS) yang paling banyak digunakan pada pasien yang dirawat dengan SIRS atau sepsis di ICU sebagai antipiretik dan anti inflamasi. Kedua obat tersebut dapat mempengaruhi agregasi trombosit yang dapat kita nilai melalui tes agregasi trombosit.

Tujuan: Mengetahui perbedaan pengaruh pemberian parasetamol dan parecoxib terhadap aktivitas agregasi trombosit pada pasien SIRS atau sepsis.

Metode: Penelitian ini merupakan penelitian eksperimental dengan pendekatan uji klinis dengan rancangan penelitian pre dan post. Terdapat 34 subjek penelitian pasien SIRS atau sepsis yang dirawat di ICU dengan umur antara 17 - 65 tahun. Distribusi sampel meliputi 17 subjek dengan pemberian parasetamol dan 17 subjek dengan pemberian parecoxib. Setelah dilakukan pengacakan dilakukan pemeriksaan agregasi trombosit sebelum perlakuan dan 120 menit sesudah perlakuan dengan menggunakan induktor 10 $\mu \mathrm{M}$ ADP.

Hasil: Berdasarkan hasil uji beda Mann Whitney pada kelompok tidak berpasangan mendapatkan nilai $p=0,310$, yang berarti bahwa tidak ada perbedaan yang signifikan dalam hal agregasi trombosit antara kelompok parasetamol dan parecoxib sebelum perlakuan dan nilai $p=0,013(p<0,05)$, yang berarti bahwa terdapat perbedaan yang signifikan antara kelompok parasetamol dan parecoxib setelah perlakuan. Analisa selanjutnya berdasarkan hasil uji beda Wilcoxon pada kelompok berpasangan mendapat nilai $p=0,020(p<0,05)$ yang berarti bahwa terdapat perbedaan yang signifikan antara sebelum dan sesudah pemberian parasetamol.
\end{abstract}

Kesimpulan: Penggunaan parasetamol akan berdampak pada penurunan agregasi trombosit secara signifikan secara statistik dibandingkan dengan parecoxib $(p=0,013)$.

Kata kunci: agregasi trombosit; parasetamol; parecoxib; OAINS; sepsis

\section{PENDAHULUAN}

SIRS atau sepsis merupakan penyebab utama morbiditas dan mortalitas di ICU. Tingginya biaya perawatan, kualitas hidup setelahnya, dan beban ekonomi yang harus ditanggung, membuat sepsis menjadi masalah kesehatan yang besar. ${ }^{1}$

Prevalensi SIRS sangat tinggi. Studi oleh Martin et al tahun 2003 memperkirakan insidensi sepsis di Amerika Serikat sebanyak 240 kasus per 100.000 orang, sedangkan Angus et al tahun 2001 melaporkan 300 kasus sepsis berat per 100.000 orang. ${ }^{2,3}$ Insiden diproyeksikan meningkat sebanyak $1,5 \%$ per tahun, mencakup sepertiga dari total pasien rawat inap dan $>50 \%$ dari seluruh pasien ICU, sedangkan di ICU bedah, SIRS dapat mencakup $>80 \%$ pasien.

SIRS adalah respon klinis terhadap rangsangan (insult) spesifik dan nonspesifik. SIRS didiagnosis apabila terdapat 2 atau lebih dari 4 variabel berikut: (1) suhu lebih dari $38^{\circ} \mathrm{C}$ atau kurang dari $36^{\circ} \mathrm{C}$; (2) denyut jantung lebih dari $90 \mathrm{kali} / \mathrm{menit}$; (3) frekuensi napas lebih dari $20 \mathrm{kali} / \mathrm{menit}$ atau tekanan parsial karbon dioksida $\left(\mathrm{PaCO}^{2}\right)$ kurang dari $32 \mathrm{mmHg}$; (4) leukosit $>12.000 / \mu \mathrm{L}$ atau $<4.000 / \mu \mathrm{L}$ atau $>10 \%$ bentuk imatur. ${ }^{4}$

Pada pasien yang mengalami SIRS dan sepsis dapat terjadi aktivasi trombosit secara langsung oleh endotoksin atau sitokin pro inflamasi yang 
mengakibatkan konsumsi yang berlebihan dan menurunnya produksi trombosit karena hemofagositosis dari megakariosit. Aktivitas yang berlebihan ini mengakibatkan berkurangnya fibrinogen, trombositopenia, faktorfaktor koagulasi dan fibrinolisis. Keadaan ini selanjutnya mengakibatkan peningkatan konsumsi trombosit dan protein koagulasi, serta meluasnya trombosis dan deposit fibrin pada mikrovaskular. Selanjutnya trombosis mikrovaskular dan iskemik akan memberikan kontribusi terjadinya cedera jaringan dan disfungsi organ multipel. Apabila gangguan proses koagulasi ini tidak teratasi akan meningkatkan angka morbiditas dan mortalitas pasien yang dirawat dengan SIRS dan sepsis. ${ }^{5}$

Prostaglandin, berperan penting dalam memperantarai reaksi pelepasan dan agregasi. Kolagen dan epinefrin mencetuskan aktivasi dari satu atau lebih fosfolipase yang ada dalam membran trombosit. Fosfolipase ini kemudian menghidrolisa fosfolipid membran, melepaskan asam arakhidonat. Asam arakhidonat dimetabolisme oleh enzim siklooksigenase untuk membentuk prostaglandin endoperoksida yang tidak stabil, kemudian dirubah menjadi tromboksan A2. Tromboksan A2 adalah suatu substansi yang sangat poten menginduksi agregasi dan sekresi trombosit. $^{6}$

OAINS merupakan obat analgesik dan antipiretik yang bekerja pada proses tranduksi dengan menghambat sintesa prostaglandin melalui penghambatan enzim siklo-oksigenase. Berdasarkan penelitian Hamilton tahun 2014, peran utama OAINS dalam menghambat perkembangan infeksi dari streptokokus Grup A menjadi bentuk infeksi yang lebih berat didasarkan pada kemampuan obat golongan ini dalam mencegah umpan balik negatif sehingga menghambat produksi dari TNF $\alpha-\mathrm{a}$ yang merupakan mediator kunci dari sepsis. $^{7}$ Beberapa penelitian terhadap hewan coba juga menyarankan penggunaan OAINS selektif Cyclooxygenase-2 (COX-2) untuk tambahan terapi pada hewan coba yang menderita sepsis. ${ }^{8,9}$

Parasetamol adalah OAINS yang paling banyak digunakan pada pasien yang dirawat dengan SIRS atau sepsis di ICU sebagai anti piretik dan anti inflamasi. ${ }^{10-}$ 14 Parecoxib adalah OAINS selektif COX-2 yang mulai banyak digunakan sebagai terapi pada pasien dengan SIRS dan sepsis. Parecoxib sodium merupakan satu-satunya OAINS yang dapat diberikan secara intravena dengan metabolit aktifnya berupa valdexocib. Mekanisme kerjadari parecoxib dengan menghambat enzim COX-2 yang memediasi sintesis prostaglandin. Pada konsentrasi plasma pada manusia valdecoxib sebagai metabolit aktif dari parecoxib tidak menghambat cyclooxygenase-1 (COX- 1). ${ }^{15}$ OAINS golongan ini juga mulai banyak digunakan sebagai terapi pada pasien dengan SIRS atau sepsis untuk mengurangi demam akibat proses inflamasi.

Beberapa penelitian sebelumnya telah menyatakan bahwa parasetamol tidak mempengaruhi fungsi platelet secara in vivo berdasarkan studi dengan menggunakan parasetamol sediaan oral. Secara in vitro, parasetamol diketahui menghambat agregasi trombosit tergantung dosis yang diberikan. ${ }^{16}$ Sedangkan penelitian oleh Mattia dan Coluzzi tahun 2009 serta Buck tahun 2011 menyatakan bahwa parasetamol tidak menghambat COX-1 dan tromboksan, sehingga efeknya terhadap gangguan lambung kecil dan juga 
tidak mempengaruhi agregasi trombosit. ${ }^{17,18}$ Berbeda dengan obat OAINS pada umumnya, mekanisme kerja utama dari parasetamol adalah menghambat cyclooxygenase-3 (COX3 ) yang terdapat di susunan saraf pusat dan selektif terhadap COX-2, sehingga tidak secara signifikan menghambat produksi tromboksan. ${ }^{19}$ Penelitian lain menyebutkan bahwa parecoxib tidak mempunyai efek menghambat agregasi trombosit. ${ }^{16,20}$

Berdasarkan uraian latar belakang diatas, maka peneliti ingin mengetahui perbedaan aktivitas agregasi trombosit yang dihasilkan setelah pemberian parasetamol dan parecoxib yang digunakan sebagai terapi tambahan pada pasien dengan SIRS dan sepsis. Dari hasil penelitian ini, diharapkan dapat menjadi dasar acuan untuk pemilihan dan penggunaan obat golongan OAINS yang digunakan sebagai terapi pada pasien dengan SIRS atau sepsis.

\section{METODE}

Penelitian ini merupakan penelitian eksperimental dengan pendekatan uji klinis dengan rancangan penelitian pre dan post yang meneliti perbedaan pengaruh pemberian parasetamol dan parecoxib terhadap aktivitas agregasi trombosit pada pasien SIRS atau sepsis. Populasi yang diikutsertakan dalam penelitian ini adalah semua pasien yang menderita SIRS atau sepsis berumur antara 17-65 tahun di ICU Rumah Sakit Umum Daerah Dr. Moewardi Surakarta dalam kurun waktu bulan SeptemberOktober 2016.

Pada penelitian ini terdapat dua variabel bebas yaitu parasetamol dan parecoxib. Sampel sebanyak 34 subjek terdiri dari kelompok 1 (mendapat terapi parasetamol) sebanyak 17 subjek dan kelompok 2 (mendapat terapi parecoxib) sebanyak 17 subjek dengan menggunakan kriteria inklusi dan eksklusi. Kriteria inklusi yaitu: (1) pasien berusia 17-65 tahun; (2) pasien SIRS atau sepsis yang dirawat di ICU Rumah Sakit Umum Daerah Dr. Moewardi Surakarta dalam kurun waktu bulan September-Oktober 2016; (3) bersedia menjadi subjek penelitian dengan menandatangani formulir persetujuan setelah mendapatkan penjelasan (informed consent). Kriteria eksklusi yaitu: (1) pasien dengan kontraindikasi pemakaian obat yang digunakan yaitu parasetamol dan parecoxib; (2) pasien yang mendapat terapi golongan OAINS selain parasetamol; (3) pasien yang mendapat terapi golongan OAINS selain parecoxib; mengkonsumsi

(4) pasien yang obat-obatan antikoagulan dan sejenisnya; (5) pasien dengan kadar trombosit $<100.000 / \mu \mathrm{L}$ atau $>400.000 / \mu \mathrm{L}$; (6) pasien yang mendapat pemberian tranfusi darah selama perlakuan; (7) pasien riwayat diabetes melitus; (8) pasien dengan penyakit hepar.

\section{Penelitian dilaksanakan di ICU RSUD} Dr. Moewardi Surakarta setelah mendapatkan persetujuan komite etik. Tata cara dilakukan sebagai berikut : (1) pasien SIRS atau sepsis yang dirawat di ICU Rumah Sakit Umum Daerah Dr. Moewardi Surakarta; (2) dilakukan informed consent mengenai tata cara, tujuan dan manfaat penelitian; (3) dilakukan identifikasi identitas (nama, jenis kelamin, umur, dan nomor rekam medik), berat badan, dan pemantauan vital sign (tekanan darah, nadi, dan suhu badan); (4) diambil sampel I darah vena sebanyak $10 \mathrm{ml}$ dan dimasukkan dalam tabung vacutainer, dikocok perlahan; (5) diberikan parasetamol $20 \mathrm{mg} / \mathrm{kgBB}$ intravena atau parecoxib $40 \mathrm{mg}$ intravena dengan volume masing- 
masing $100 \mathrm{ml}$ selama 30 menit; (6) kemudian ditunggu selama 120 menit untuk parasetamol dan parecoxib sampai tercapai kadar puncak dalam plasma; (7) setelah 120 menit diambil sampel II darah vena sebanyak $10 \mathrm{ml}$ dan dimasukkan ke dalam tabung vacutainer, dikocok perlahan; (8) kedua sampel darah kemudian dibawa ke laboratorium untuk diolah.

Data yang didapatkan dilakukan analisis dengan menggunakan komputer. Data demografi dan hasil penelitian dinilai apakah distribusinya normal atau tidak. Untuk menguji aktivitas agregasi trombosit sebelum dan sesudah diberikan parasetamol intravena 20 $\mathrm{mg} / \mathrm{kgBB}$ dan parecoxib $40 \mathrm{mg}$ menggunakan uji beda agregasi trombosit antara kedua kelompok perlakuan tersebut. Penelitian ini menggunakan data kategori dengan skala ordinal sehingga uji beda dilakukan dengan uji statistik nonparametrik. Uji beda pada kelompok tidak berpasangan menggunakan uji Mann Whitney. Sedangkan uji beda pada kelompok sampel berpasangan menggunakan uji Wilcoxon.

\section{HASIL}

Berdasarkan hasil penelitian yang telah dilakukan pada 34 pasien SIRS atau sepsis yang dirawat di ICU RSUD Dr. Moewardi Surakarta, didapatkan gambaran karakteristik subjek penelitian seperti Tabel 1. Berdasarkan Tabel 1 diketahui bahwa mayoritas pasien pada kelompok parasetamol berjenis kelamin laki-laki $(64,7 \%)$, sedangkan pada kelompok parecoxib mayoritas perempuan $(52,9 \%)$. Nilai $p=0,300$ $(p>0,05)$ yang berarti bahwa tidak terdapat perbedaan yang signifikan mengenai karakteristik responden berdasarkan jenis kelamin antara kelompok parasetamol dengan kelompok parecoxib, sehingga karakteristik responden berdasarkan jenis kelamin pada kedua kelompok homogen.

Tabel 1.Karakteristik responden

\begin{tabular}{lccc}
\hline \multirow{2}{*}{ Karateristik } & \multicolumn{2}{c}{ Kelompok } & \multirow{2}{*}{$p$} \\
\cline { 2 - 3 } & Parasetamol & Parecoxib & 0.300 \\
Jenis Kelamin* & $11(64.7 \%)$ & $8(47.1 \%)$ & \\
Laki-laki & $6(35.3 \%)$ & $9(52.9 \%)$ & \\
Perempuan & $44.47 \pm 11.70$ & $44.24 \pm 14.97$ & 0.960 \\
Umur (Tahun)** & $57.41 \pm 7.12$ & $55.71 \pm 6.80$ & 0.480 \\
Berat Badan (Kg)** & & & 1.000 \\
Tekanan Darah* & $3(17.6 \%)$ & $3(17.6 \%)$ & \\
Hipotensi & $14(82.4 \%)$ & $14(82.4 \%)$ & \\
Normotensi & $101.35 \pm 7.52$ & $106.24 \pm 8.64$ & 0.089 \\
Denyut Jantung** & $19.29 \pm 3.57$ & $19.76 \pm 3.05$ & 0.740 \\
Laju Napas*** & $37.31 \pm 0.79$ & $37.15 \pm 0.62$ & 0.532 \\
Suhu $\left({ }^{0}\right.$ C)** & $13.86 \pm 5.06$ & $17.31 \pm 9.12$ & 0.183 \\
Leukosit** & & & \\
\hline Keterangan: & & & \\
\hline
\end{tabular}

Keterangan:

* Data Kategori (Jumlah, Prosentase) Uji Chi Square

** Data numerikdistribusi normal (Mean + SD ) Uji Independen Sampel T test

*** Data numerikdistribusi tidak normal (Mean + SD ) Uji Mann Whitney 
Tabel 2. Uji beda agregasi trombosit antara parasetamol dan parecoxibsebelum perlakuan

\begin{tabular}{|c|c|c|c|}
\hline \multirow{2}{*}{ Variabel } & \multicolumn{2}{|c|}{ Kelompok } & \multirow{2}{*}{$p$} \\
\hline & Parasetamol & Parecoxib & \\
\hline Agregasi Trombosit (pre) & & & 0,310 \\
\hline Hipoagregasi & $2(11,8 \%)$ & $3(17,6 \%)$ & \\
\hline Normoagregasi & $7(41,2 \%)$ & $9(52,9 \%)$ & \\
\hline Hiperagregasi & $8(47,1 \%)$ & $5(29,4 \%)$ & \\
\hline
\end{tabular}

Tabel 3. Uji beda agregasi trombosit antara parasetamol dan parecoxib sesudah perlakuan

\begin{tabular}{lccc}
\hline \multirow{2}{*}{ Variabel } & \multicolumn{2}{c}{ Kelompok } & \multirow{2}{*}{$p$} \\
\cline { 2 - 3 } & Parasetamol & Parecoxib & 0,013 \\
Agregasi Trombosit (post) & $2(11,8 \%)$ & $1(5,9 \%)$ & \\
Hipoagregasi & $14(82,4 \%)$ & $8(47,1 \%)$ & \\
Normoagregasi & $1(5,9 \%)$ & $8(47,1 \%)$ & \\
Hiperagregasi & &
\end{tabular}

Tabel 4. Uji beda agregasi trombosit pre-post pada kelompok parasetamol

\begin{tabular}{lcc}
\hline \multicolumn{1}{c}{ Uji beda Wilcoxon } & \\
\hline \multicolumn{1}{c}{ Agregasi trombosit post - agregasi trombosit pre } & Jumlah & $p$ \\
\hline Negative Ranks (Penurunan) & 8 & 0,020 \\
Positive Ranks (Peningkatan) & 1 & \\
Ties (Tidak Berubah) & 8 & \\
Total & 17 & \\
\hline
\end{tabular}

Tabel 5. Uji beda agregasi trombosit pre-post pada kelompok parecoxib $40 \mathrm{mg}$

\begin{tabular}{lcc}
\hline \multicolumn{3}{c}{ Uji beda Wilcoxon } \\
\hline \multicolumn{1}{c}{ Agregasi trombosit post - agregasi trombosit pre } & Jumlah & $p$ \\
\hline Negative Ranks (Penurunan) & 1 & 0,056 \\
Positive Ranks (Peningkatan) & 6 & \\
Ties (Tidak Berubah) & 10 & \\
Total & 15 & \\
\hline
\end{tabular}


Berdasarkan Tabel 2, sebelum adanya perlakuan diketahui bahwa pada kelompok parasetamol sebagian besar dengan agregasi trombosit dalam kategori hiperagregasi yaitu sebanyak 8 pasien $(47,1 \%)$, sedangkan pada kelompok parecoxib sebagian besar dengan agregasi trombosit dalam kategori normoagregasi yaitu sebanyak 9 pasien $(52,9 \%)$. Berdasarkan hasil uji beda Mann Whitney mendapatkan nilai $p=0,310 \quad(p>0,05)$, yang berarti bahwa tidak ada perbedaan yang signifikan dalam hal agregasi trombosit antara kelompok parasetamol dan parecoxib sebelum perlakuan.

Berdasarkan Tabel 3, sesudah adanya perlakuan diketahui bahwa pada kelompok parasetamol sebagian besar dengan agregasi trombosit dalam kategori normoagregasi yaitu sebanyak 14 pasien $(82,4 \%)$, sedangkan pada kelompok parecoxib sebagian besar dengan agregasi trombosit dalam kategori normoagregasi dan hiperagregasi yaitu masing-masing sebanyak 8 pasien $(47,1 \%)$. Berdasarkan tabel diatas diketahui terdapat kecenderungan bahwa penggunaan parasetamol mempengaruhi trombosit menjadi cenderung hipoagregasi, sedangkan pada kelompok parecoxib mempengaruhi trombosit menjadi cenderung hiperagregasi. Berdasarkan hasil uji beda Mann Whitney mendapatkan nilai $\mathrm{p}=0,013 \quad(\mathrm{p}<0,05)$, yang berarti bahwa terdapat perbedaan agregasi trombosit yang signifikan antara kelompok parasetamol dan parecoxib setelah perlakuan.

Berdasarkan Tabel 4, diketahui bahwa setelah pemberian parasetamol 20 $\mathrm{mg} / \mathrm{KgBB}$ terdapat 8 pasien yang mengalami penurunan agregasi trombosit, dan 1 pasien yang mengalami peningkatan agregasi trombosit.
Sedangkan 8 pasien agregasi trombositnya tetap. Nilai $\mathrm{p}=0,020$ $(\mathrm{p}<0,05)$ menunjukkan bahwa terdapat perbedaan yang signifikan dalam agregasi trombosit antara sebelum dan sesudah pemberian parasetamol 20 $\mathrm{mg} / \mathrm{KgBB}$. Sehingga dapat dikatakan bahwa pemberian parasetamol 20 $\mathrm{mg} / \mathrm{KgBB}$ mampu menghambat bahkan menurunkan aktivitas agregasi trombosit.

Berdasarkan Tabel 5, setelah pemberian parecoxib $40 \mathrm{mg}$ diketahui bahwa terdapat 1 pasien yang mengalami penurunan agregasi trombosit, yang mengalami peningkatan agregasi trombosit ada 6 pasien. Sedangkan yang tidak berubah kategori agregasi trobosit ada 10 pasien. Nilai $p=0,056(p>0,05)$ yang berarti bahwa tidak terdapat perbedaan yang signifikan dalam agregasi trombosit antara sebelum dan sesudah pemberian parecoxib 40 $\mathrm{mg} / \mathrm{kgBB}$. Sehingga dapat dikatakan bahwa pemberian parecoxib $40 \mathrm{mg}$ hanya mampu menghambat aktivitas agregasi trombosit.

\section{PEMBAHASAN}

Hasil penelitian ini menunjukan bahwa pemberian parasetamol tidak berpengaruh terhadap agregasi trombosit, ditunjukkan dengan hasil normoagregasi pada 14 pasien $(82,4 \%)$, sedangkan parecoxib berpengaruh terhadap agregasi trombosit, ditunjukkan dengan hasil normoagregasi dan hiperagregasi yaitu masing-masing ada 8 pasien $\quad(47,1 \%)$ Penggunaan parasetamol cenderung pada agregasi trombosit dalam kategori normoagregasi ke hipoagregasi, sedangkan pada kelompok parecoxib cenderung normoagregasi ke hiperagregasi. Berdasarkan hasil uji statistik mendapatkan nilai $\mathrm{p}=0,013 \quad(\mathrm{p}<0,05)$, yang berarti bahwa terdapat perbedaan 
yang signifikan dalam agregasi trombosit antara kelompok parasetamol, dan parecoxib setelah perlakuan. Dimana penggunaan parasetamol cenderung menurunkan agregasi trombosit dibandingkan dengan parecoxib.

Aksi utama dari parasetamol adalah menghambat sintesis prostaglandin dengan cara inhibisi sentral enzim COX3 yang diinduksi di susunan saraf pusat. ${ }^{17}$ Inhibisi enzim COX-3 ini akan mengurangi konsentrasi prostaglandin E2 sehingga menurunkan ambang batas hipotalamus untuk menurunkan panas, dan aktivasi jalur inhibisi serotonergik descenden untuk menghasilkan analgesia. ${ }^{17,18}$ Parasetamol diketahui secara selektif mampu menghambat kerja COX-3 yang sejumlah besar terdapat dalam korteks serebri sehingga sintesis prostaglandin pun dapat dihambat. Parasetamol sendiri mampu menembus sawar darah otak, sehingga efek antipiretik parasetamol lebih efektif dibandingkan OAINS lainnya. Karena parasetamol tidak menghambat COX-1, maka efeknya terhadap gangguan lambung juga kecil dan tidak memiliki efek terhadap agregasi trombosit. ${ }^{21,22}$

Sedangkan parecoxib merupakan OAINS spesifik menghambat COX-2. COX-2 sebagai enzim bertugas merubah prostaglandin $\mathrm{H} 2$ menjadi prostaglandin E2 yang berperan dalam kejadian inflamasi, nyeri dan demam. Pada konsentrasi plasma pada manusia valdecoxib tidak menghambat siklooksigenase-1 (COX-1). Pada sediaan binatang, valdecoxib sebagai OAINS, analgetik dan antipiretik. Parecoxib merupakan salah satu inhibitor COX-2 yang merupakan turunan dari valdecoxib yang bersifat larut dalam air. Parecoxib ini menyebabkan retensi natrium, menurunkan produksi prostaglandin dan resistensi efek natriuretik sehingga menimbulkan retensi cairan dan peningkatan tekanan darah. Parecoxib tidak berpengaruh terhadap fungsi trombosit atau waktu perdarahan. Valdecoxib dimetabolisme secara luas di hati dengan banyak cara, termasuk cytochrome p450, isoenzim 3A4 dan 2 C9. Kurang dari $5 \%$ valdecoxib yang tidak berubah dikeluarkan lewat urin. Sekitar 70\% dari dosis dieksresi lewat urin sebagai metabolit yang tidak aktif. Waktu paruh eliminasi valdecoxib sekitar 8 jam. ${ }^{15}$

Hasil penelitian ini sejalan dengan Musterhjelm tahun 2006 yang meneliti tentang karakteristik parasetamol intravena dan interaksinya dengan diklofenak dan parecoxib terhadap penghambatan aktivitas agregasi trombosit pada orang sehat. ${ }^{16}$ Pemberian parasetamol intravena secara signifikan menghambat aktivitas agregasi trombosit melalui penghambatan asam arakhidonat dan tromboksan A2. Musterhjelm et al, tahun 2005 meneliti efektivitas pemberian parasetamol berdasarkan dosis terhadap agregasi trombosit pada orang sehat, hasilnya secara signifikan parasetamol menghambat agregasi trombosit dalam kurun waktu 90 menit setelah pemberian intravena. ${ }^{23}$ Parasetamol memiliki sifat dose dependent terhadap penghambatan agregasi trombosit. Selain itu, berdasarkan penelitian Noveck dan Laurent tahun 2001, pemberian parexocib 40mg intravena dua kali sehari tidak memberikan efek terhadap agregasi trombosit pada individu sehat, dimana hasil ini sesuai dengan mekanisme inhibitor spesifik COX$2.24,25$

Pengunaan parasetamol dengan dosis 20 mg per kilogram berat badan dipilih 
berdasarkan pada penelitian sebelumnya yang dilakukan oleh Janz et al tahun 2015 yang meneliti kemampuan parasetamol sebagai terapi tambahan untuk mengurangi cedera oksidatif pada pasien dewasa yang mengalami sepsis berat. ${ }^{13}$ Dosis $20 \mathrm{mg}$ perkilogram berat badan juga sesuai dengan penelitan Viscuzi et al tahun 2012 yang menyatakan bahwa untuk pasien dewasa berusia diatas 13 tahun atau memiliki berat badan di atas $50 \mathrm{~kg}$, dosis parasetamol yang diberikan untuk single dose maksimal adalah $1000 \mathrm{mg}$ atau sekitar $20 \mathrm{mg}$ per kilogram berat badan dengan asumsi berat badan pasien adalah $50 \mathrm{~kg}^{17}$

\section{KESIMPULAN}

Berdasarkan hasil penelitian penggunaan parasetamol akan berdampak pada penurunan agregasi trombosit dibandingkan dengan penggunaan parecoxib pada pasien SIRS atau sepsis di ICU.

\section{DAFTAR PUSTAKA}

1. Dhillon A, Bittner E. Nonantibiotic therapies for sepsis. Dalam : Critical care handbook of the massachusetts general hospital. 5th ed. Philadelphia: Lippincot Williams \& Wilkins; 2010. hal 447

2. Martin GS, Mannino DM, Eaton S, Moss M.The epidemiology of sepsis in the United States from 1979 through 2000. EnglJ Med.2003; 348: 1546-1554

3. Angus DC, Linde-Zwirble WT, Lidicker J, Clermont G, Carcillo J, Pinsky MR. Epidemiology of severe sepsis in the united states: analysis of incidence, outcome, and associated costs of care. Critc Care Med. 2001; 29: 1303-10

$\begin{array}{llrr}\text { 4. } & \text { Leksana } & \text { E. } & \text { Systemic } \\ \text { Inflammatory } & & \text { Response } \\ \text { Syndrome. } & \text { Cermin } & \text { Dunia }\end{array}$

Kedokteran. 2013;40 (1): 7-11

5. Rello J, Diaz, E, Rodriquez A. Management of sepsis: The PIRO Approach. Berlin : SpringerVerlag; 2009. hal 147

6. Munford, RS. Severe sepsis and septic shock. Dalam : Harison's Principles of internal medicine. 18th ed. New York: McGraw-Hill; 2011: 502-07

7. Hamilton SM, Bayer CR, Stevens DL, Bryant, AE. Effects of selective and nonselective nonsteroidal anti-inflammatory drugs on antibiotic efficacy of experimental group a streptocomlal myonecrosis. $\mathrm{J}$ of Infection Disease. 2014; 209: 1429-35

8. Kara E, Var A, Vatansever S, Cilaker S, Kaya Y,Cokun Y. Effects of rofecoxib, a selective cyclooxygenase-2 inhibitor on endothelial dysfunction, lipid peroxidation and hepatocyte morphology in rats with sepsisinduced liver damage. Cur Thera research. 2004; 65 (3): 278-91

9. Chong SJ, Wong YC, Wu J, Tan $\mathrm{MH}, \mathrm{Lu} \mathrm{J}$, Moochhala SM. Parecoxib reduces systemic inflammation and acute lung injury in burned animals with delayed fluid resuscitation. Intl J of Inflam. 2014; 73 (6): 1-11

10. Greenberg RS, Chen H, Hasday JD. Acetaminophen has limited antipyretic activity in critically ill patients. J Crit Care. 2010; 25 (2):1-13

11. Selladurai S, Eastwood GM, Bailey M, Bellomo R. Paracetamol therapy for septic critically ill patients: a retrospective observational study. Critical Care Resuscitation. 2011; 13: 181-6

12. Lee BH, InuiD, Suh GY,Kim JY, Kwon JY, Park J,Tada K et al. 
Association of body temperature and antipyretic treatments with mortality of critically ill patients with and without sepsis: multicentered prospective observational study. CritCare, 2012;16:1-13

13. Janz DR, Bastarache JA, Rice TW,Bernard GR, Warren MA, Wickersham $\mathrm{N}$ et al.Randomized, placebo-controlled trial of acetaminophen for the reduction of oxidative injury in severe sepsis: the ACROSS trial. Crit Care Med. 2015; 43 (3): 534-41

14. Husain AA dan Martin GS. What's old is new again: acetaminophen as a novel approach to treating sepsis. CritCare Med. 2015; 43 (3): 69899

15. Ferdinand J, Brahmi NH, Sasongko H. Pengaruh pemberian ketorolak dan parecoxib intramuskuler terhadap gambaran histopatologi tubulus proksimal ginjal tikus wistar. Jurnal Anestesi Indonesia. 2014; 8 (2): 125-37

16. Munsterhjelm E. Characterization of Inhibition of Platelet Function by Paracetamol and its Interaction with Diclofenac and Parecoxib. [Disertasi] Helsinki; Universitas Helsinki; 2006: 1-53

17. Mattia C, Coluzzi F. What anesthesiologists should know about paracetamol (acetaminophen). Minerva Anest. 2009; 75: 644-53

18. Viscusi ER., Singla N, Gonzalez A, Saad N, Stepanian J. Intravenous acetaminophen improves pain management and reduces opioid requirements in surgical patients. A review of the clinical data and case-based presentations. 2012:1-8

19. Rosenquist RW dan Vrooman BM.. Chronic pain management.
Dalam: Morgan dan mikhail's clinical anesthesiology. 5th ed. New York: McGraw-Hill; 2013: 1023-85

20. Leese PT, Recker DP, Kent JD. The COX-2 selective inhibitor, valdecoxib, does not impair platelet function in the elderly: results of a randomized controlled trial. The J of Clin Pharm. 2003; 43 (5): 504-13

21. Baley K, Michalov K, Kossick MA, McDowell M. Intravenous acetaminophen and intravenous ketorolac for management of pediatric surgical pain: a literature review. American Assoc of Nurse Anesth J.2014; 82 (1): 53-64

22. Munsterhjelm E, Niemi TT, YlikorkalaO, Neuvonen PJ, Rosenberg $\mathrm{PH}$. Influence on platelet aggregation of i.v. parecoxib and acetaminophen in healthy volunteers. Brit $\mathrm{J}$ of Anaesth. 2006; 2: 226-31

23. Timothy DW, Jane AM. Cyclooxygenase-3 (COX-3): filling in the gaps toward a $\mathrm{COX}$ continum. Proceedings of the Nat Academy of Sci. 2001; 99 (21): 133-41

24. Noveck RJ, Laurent A, Kuss M, Talwalker S, Hubbard RC. Parecoxib sodium does not impair platelet fuction in healthy elderly and non-elderly individuals. Clin Drug Invest. 2001; 21 (7): 465-76

25. Ferrari, R. A, Ward, S. J., Zobre, C. M., Van Liew, D. K., Perrone, M. H., Connell, M. J. and Haubrich, D. R. (1990). Estimation of the in vivo effect of cyclooxygenase inhibitors on prostaglandin $\mathrm{E}_{2}$ levels in mouse brain, Eur. J. Pharmacol. 179, 25-34 